\title{
Is the hydrogen-powered train a possibility for Hong Kong's new railway projects?
}

\author{
Jacky Ping Pan Chan \\ MTR Corporation, Hong Kong, People's Republic of China
}

\begin{abstract}
Prized for its emission-free nature, cutting-edge hydrogen fuel cell technology is maturing and thus gaining global interest. As a sustainable energy source and storage, hydrogen power has grown into a possible solution to curtail global warming. In the transport industry, the hydrogen train has been seen as a successful application in Germany. With the new railway project opportunities in Hong Kong, this study will examine the preliminary feasibility of introducing hydrogen trains to this cosmopolitan city in Asia. This paper focuses on the socio-economic impact on various stakeholders as a qualitative analysis. The carbon footprint savings in switching to hydrogen train operation is estimated as quantitative analysis.
\end{abstract}

KEYWORDS Hydrogen power; railway; rolling stock; renewable energy; fuel cell

CONTACT Ping Pan Chan chanpingpan@gmail.com

Received 18 July 2020

\section{Introduction}

The train, in Chinese literally "fire vehicle", has an interesting story in China. Its Chinese name comes from the sight of a moving machine with smoke and sparks emitted from a coal-burning steam power locomotive. In the 196 years since the first introduction of the public steam railway in England in 1825, the traction power and fuel source of the locomotive has been a leapfrog development. From steam to electric to diesel, however, all energy sources have originated from fossil fuels. While electrical energy is already the most widely used form of energy, driving every part of the civilised community, people are aware of the drawbacks brought by the generation and distribution of this power: carbon emissions, the greenhouse effect, and the end result, global warming. When it comes to the railway, electricity can be regained through consumption by means of regenerative braking. The train can feed the excess electricity generated by this advanced braking technology to the overhead line power system during train operation. This harnessed energy can be stored in the supercapacitor for later use. Still, scientists and engineers are working on sustainable energy resources to lessen the impact of global warming over the last few decades.

As an alternative with lower carbon emissions, hydrogen cells have attracted public attention owing to their harmless waste product, water. One may think that hydrogen as a power source on trains is a bold idea. Yet it is a feasible solution, given today's advancements in hydrogen fuel cell research. One of the leading rolling stock manufacturers, Alstom, successfully produced the world's first hydrogen train, Coradia iLint. (Alstom, 2020) Bypassing the traditional system of overhead lines, this state-of-the-art rolling stock is currently undergoing testing and commissioning in Europe. As a possible environmentally friendly and infrastructure- saving alternative to overhead lines, the question is: Is the hydrogen-powered train a possibility for Hong Kong's new railway projects?

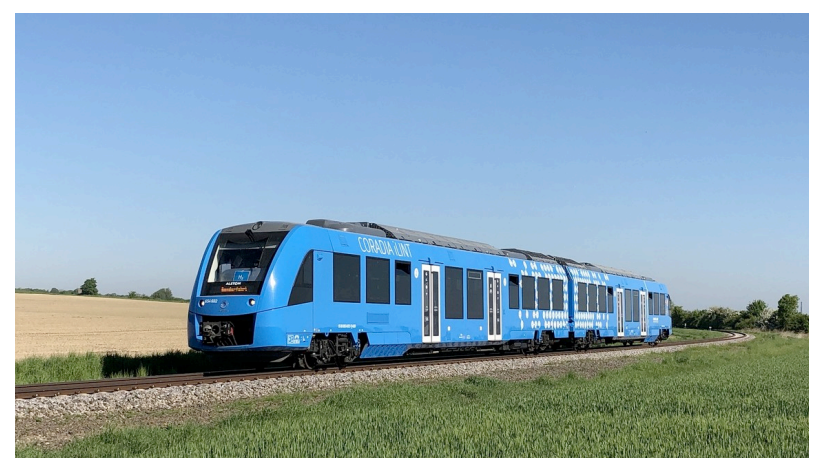

Figure 1. World's first hydrogen train Coradia iLint (Alstom, 2020).

\section{Background}

\subsection{Hydrogen cell development, principles and application in railways}

Hydrogen fuel cell development is nothing new. While the world's first fuel cell was created by Sir William Robert Grove in 1839 (The Environmental Literacy Council, 2015), its breakthrough in the transport sector appeared with the introduction of the first hydrogen fuel cell vehicle, the Tuscon FCEV produced by Hyundai in 2013 (Matthew, 2013). Backed by the German government, the rolling stock giant Alstom grasped the potential of the hydrogen train technology in 2016 and delivered the innovative rolling stocks Coradia iLint to regional rail operators in Lower Saxony, Germany. It is expected to replace the diesel fleets in Britain and the Netherlands (Alstom, 2020). 
The working principle of a hydrogen fuel cell is based on the simple chemical equation of hydrogen and oxygen gas combustion:

$$
2 \mathrm{H}_{2}(\mathrm{~g})+\mathrm{O}_{2}(\mathrm{~g}) \rightarrow 2 \mathrm{H}_{2} \mathrm{O}(\mathrm{l})+\text { energy. }
$$

Hydrogen and oxygen are two abundant elements on Earth that can be found in water and atmospheric air. The gases can be produced by electrolysis or through industrial processes (Alstom, 2020). The fuel cell produces electrical energy by combining hydrogen and oxygen. Unlike the burning of fossil fuels which outputs carbon, nitrogen and sulphur particulates, carbon dioxide and other exhaust gases, a hydrogen cell produces energy with water as the only by-product. In rolling stock operation, the electricity created is delivered to the traction system, air conditioning, lighting, and other essential energy-consuming systems. The excess energy is stored in the train-borne lithium battery. The Alstom Coradia iLint model can carry 150 seated passengers and the same number of standing passengers in one coach, which in size is comparable to Hong Kong metro units. Capable of running at a top speed of $140 \mathrm{~km} / \mathrm{h}$, a hydrogen train's single mileage can achieve up to $1,000 \mathrm{~km}$ per single refill of gases (Verdict Media Limited, 2020). This specification also fulfils the railway operation requirements in Hong Kong. Taking West Rail Line as an example, its maximum running speed is $130 \mathrm{~km} /$ $\mathrm{h}$ with an average daily mileage of around 500-600 km for each train. Therefore, hydrogen fuel refill would be possible after one single day of revenue service.

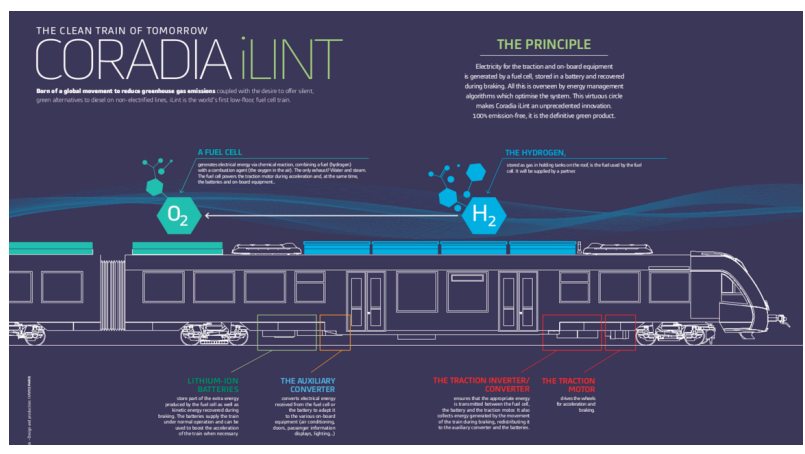

Figure 2. Overview of hydrogen train working principles (Alstom, 2020).

\subsection{Application opportunities in Hong Kong}

The Paris Agreement was signed in 2016 to combat climate change and strengthen low-carbon collaboration among countries. One of its key objectives is to reduce greenhouse gas emissions, specifically carbon dioxide, known as carbon emissions (United Nations, 2020). The Paris Agreement also applies to Hong Kong, as instructed by the Central People's Government of PRC. As such, "Climate Change Action Plan 2030+" was set out by the
Hong Kong Government, which aims to decrease its carbon emissions gradually in the next few decades, with a target of reducing emissions from 3.3 to 3.8 tonnes per capita by 2030 (Environment Bureau, 2017). Serving millions of Hong Kong commuters daily, the railway has been an important means of transport and mass transit owing to its environmentally friendly and efficient characteristics. In Hong Kong, while electricity still drives most railway systems, the hydrogen fuel cell can serve as an alternative. The reduction in electricity consumption, as a result, can help reduce carbon emissions, provide cleaner air and achieve the goals of "Climate Change Action Plan 2030+".

According to the Railway Development Strategy (RDS) 2014 rolled out by the Hong Kong Government, there are seven new railway projects to be initiated in the near future (Transport \& Housing Bureau, 2014). While four out of seven proposals are regarded as brownfield projects involving extensions or additional stations for existing rail lines, the remaining three are greenfield proposals, namely the Northern Link, the East Kowloon Line and the South Island Line (West). In the primary consideration of construction, an overhead line power distribution system is not required for hydrogen trains. Therefore, it is worth studying the feasibility of introducing the hydrogen train in these three greenfield projects, given that they will bring fewer interface issues with the existing systems than the brownfield projects.

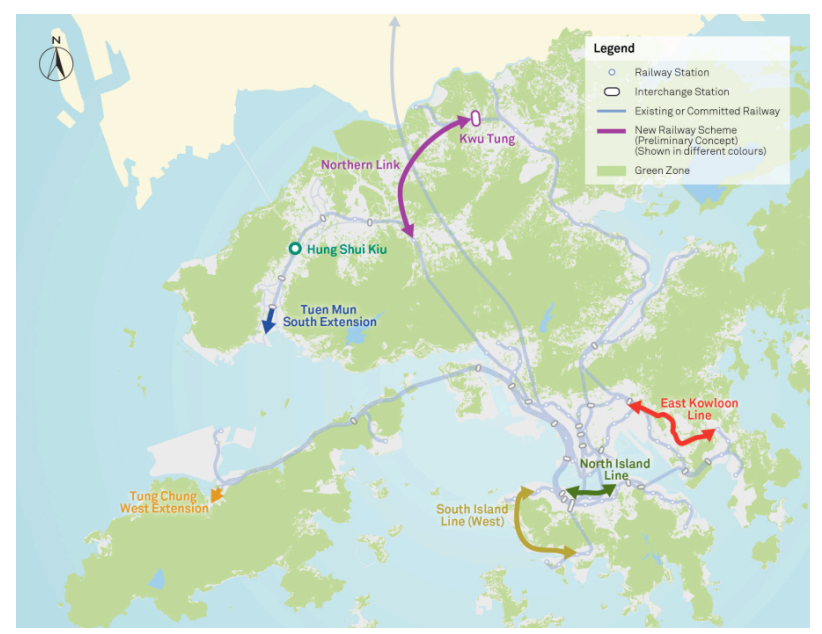

Figure 3. The seven proposals in RDS 2014 (Transport \& Housing Bureau, 2014).

In this paper, the research objective is to conduct a feasibility study of hydrogen train application in Hong Kong focusing on the socio-economic aspect. The engineering and financial analyses are not included in this study. The research question is, "What are the major considerations of introducing hydrogen trains to Hong Kong greenfield projects?" 


\section{Methodology}

A qualitative approach to studying hydrogen train archival documents, such as media and journal papers, will be adopted in this paper. A PEST analysis (shown in Figure 4) will be used to examine the major considerations of introducing hydrogen trains to Hong Kong greenfield projects, from political, economic, social, and technological perspectives. Stakeholders' interests are considered to aid in the PEST analysis. They are the regulator (government), the operator (MTR), hydrogen train and related business suppliers (technological professionals), customers (passengers), community groups (residents nearby), and environmental partners (local environmentalists).

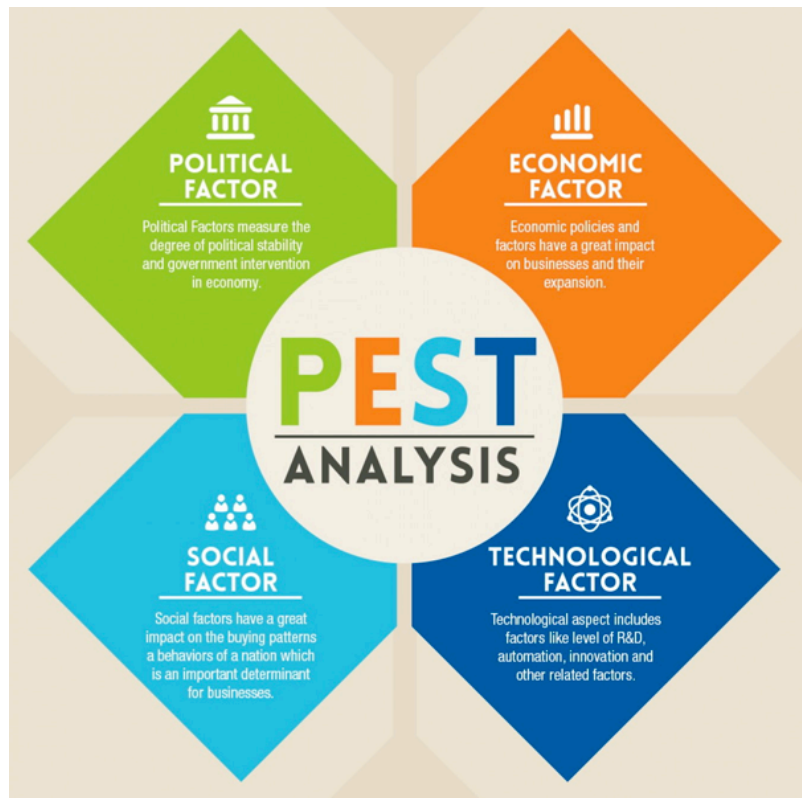

Figure 4. A representation of PEST analysis (Keyser, 2018).

The second methodology is the quantitative approach to analyse the carbon footprint savings in switching to hydrogen train operation. Carbon footprint calculation can also be used as one of the important justifications for hydrogen train application in achieving the Hong Kong Government's "Climate Change Action Plan 2030+".

\section{Results and Finding}

\subsection{PEST analysis}

\subsubsection{Political}

As the regulator of railway operation, the Hong Kong Government can benefit from introducing hydrogen trains, in that the carbon emissions from railway electricity consumption would be reduced. Hydrogen trains could help achieve the "Climate Change Action Plan 2030+", for which the savings will be discussed in section 4.2. Moreover, to align with the city's goal of transforming Hong Kong into a technology hub in Asia, the government should take this opportunity to develop new energy industries. Hydrogen technologies have enormous potential for synergistic application in other transport industries such as buses, taxis and even private cars. Hydrogen power helps reduce reliance on traditional fossil fuels, whose costs are dynamic as energy sources. The government can ride on this new energy to improve our homeland as a more liveable city, and at the same time market the Pearl of the Orient as an innovative city.

\subsubsection{Economic}

Hydrogen train technology not only brings cleaner air, but it also offers new job and investment opportunities to Hong Kong. This innovative technology attracts technological talents and associated business capital to the Hong Kong energy market. From the design and construction to the operation and maintenance stages, professionals from various engineering and business disciplines will be required in this first-ever project in Hong Kong. The financing model can be a public-private partnership (PPP) to share the stakeholders' benefits and risks.

From the railway operator's perspective, hydrogen train operation also offers benefits in reducing construction and maintenance costs for overhead line (OHL) and power distribution systems. As a major customer of electric companies, the operator can lower the demand for and reliance on electricity, and thus the cost of electricity as a complementary benefit. However, the operator will have to consider the construction, operation and maintenance costs to justify the project's financial viability. Apart from the substantial investment cost of procuring the hydrogen trains, ancillary facilities and services for recharging, storing, transporting, and maintaining hydrogen power should also be taken into account in the financial return analysis. Subject to affordability for travellers, the fare of hydrogen train services may be adjusted to offset the investment.

\subsubsection{Social}

While Hong Kong may achieve the target laid out in "Climate Change Action Plan 2030+" by reducing the carbon emissions generated by railways, the air quality improvement is a visible result of reduced demand for electricity. Every citizen, investor and visitor shall welcome this increase of social benefit in Hong Kong as a more liveable city. In addition, hydrogen technology can lead to social capital growth in the community, which should be beneficial to both the railway operator and residents. As a sustainable development, this environmentally friendly train demonstrates the railway operator's corporate 
responsibility. At the same time, environmental partners' concerns on carbon emissions can also be addressed.

From the traveller's and community's perspective, they will probably first experience a noise reduction and quieter train journey due to the absence of friction between pantograph (electricity collector on a train) and overhead lines (high voltage distribution system). Reducing the demand for electricity will also pay off in the carbon footprint of travellers. Raising all citizens' environmental protection awareness will be the final goal of this influential hydrogen train project.

Despite the various advantages brought to the major stakeholders, safety concerns on hydrogen train operation and associated services are to be expected from the community and travellers, and should be addressed carefully. Some of their worries will be discussed in the technological analysis in section 4.1.4.

\subsubsection{Technological}

Since the hydrogen train may be the first application of hydrogen technology to mobility, the government as the regulator should take the initiative of adopting new governance methods and relevant standards to ensure the system's safety and reliability. Built on the riskbased approach principle, the operator should also lead in managing the safety and reliability risks according to or even exceeding the regulatory requirements. The stringent management and supervisory controls in operating hydrogen trains, as well as transporting, storing, operating, maintaining, and disposing of the hydrogen products, should be reviewed regularly. Currently, there are very few technical professionals specialising in hydrogen power in Hong Kong. Once the project is approved, staff training with the necessary design, construction, operation and maintenance skills for the hydrogen train should be made a priority.

Given its explosive characteristic, community groups and passengers will likely raise concerns about the safety of the hydrogen train and associated hydrogen cells near tracks and hydrogen cell facilities. While hydrogen-supporting entities should be located as far as possible from residential areas in the planning stage, the mainline of the hydrogen train operation should also be maintained at a minimum safe distance from buildings, and with fences installed if deemed necessary. Public consultation and education will be of paramount importance to address local stakeholders' concerns. With a focus on safety measures, recovery plans, overseas operation examples and sustainable development, the public can be made to understand that hydrogen power is a reliable and renewable energy with proven applications worldwide.

Lastly, the environmentalists may argue whether electrical consumption in producing hydrogen fuel cells is justifiable. While the oxygen gas can be harnessed from the atmospheric air, electrical energy is required to produce pure hydrogen gas. Subsequent storage and transport of hydrogen fuel tanks also incur energy costs. Therefore, a comprehensive analysis should be conducted to justify the efficiency of the hydrogen train. To maximise the sustainability of hydrogen trains, renewable energy such as solar and wind power should be adopted and leveraged to cover all the energy costs before refilling a train's hydrogen fuel.

\subsection{Carbon emission reduction estimation}

The savings in carbon emissions that would come from the introduction of the hydrogen train to the three new greenfield projects, Northern Link, East Kowloon Line and South Island Line (West), are estimated roughly in this subsection.

The carbon emissions of electrified domestic rail is estimated as $41 \mathrm{~g}$ (or $4.519 \times 10-5$ ton) per passenger per $\mathrm{km}$ travelled, according to the UK government greenhouse gas conversion factors (BBC News, 2019). The reduction in total carbon emissions in all three new lines can be calculated based on the total estimated patronage-mileage if they are built with electrified systems. However, the carbon emissions created by the production of hydrogen and oxygen fuels is neglected, based on the initiative of utilising other renewable energies like solar and wind power. Details of calculation can be viewed in Appendix 1.

Summing up the annual carbon emissions of the three projects, the total annual CO2 savings is 190,522 tons. Taking the Hong Kong population as 7,500,700 (HKSAR Government, 2020), the savings amounts to an average of 0.025 tons per capita, or $0.7 \%$ to $0.8 \%$ of the target in "Climate Change Action Plan 2030+" by 2030.

\section{Discussion and Recommendation}

In the last section, the benefits of hydrogen train introduction mostly lie on the environmental side, such as carbon emission reduction, air quality and noise improvement. While cost-benefit and detailed financial return analyses should be conducted to justify the hydrogen operation and maintenance costs, the operator can enjoy the social responsibility achievement of introducing this green transport solution. The reputation of Hong Kong can also be enhanced in terms of liveable, innovative and environmentfriendly aspects. The Hong Kong Government and citizens can benefit from this new energy industry growth, which fosters more social and economic activities.

On the other hand, some issues will probably be raised by the stakeholders that need to be addressed. First and foremost, the safety and reliability of the hydrogen train system must be monitored and controlled carefully to international best practice standards. Risk assessments will be required in detail to mitigate the dangers arising from the construction, operation, transport and disposal of 
hydrogen products. Secondly, the potential fare increase is another key concern for passengers of the hydrogen train. Fare change can be offset by granting the operator land development rights along the rail lines, i.e., the Rail Plus Property Model.

Lastly, the environmentalists may question whether the electricity in producing hydrogen fuels is justifiable, compared with harnessing power directly from the electrified overhead line systems. The estimated carbon emissions will contribute only $0.7 \%-0.8 \%$ of the government reduction target, which, in a sense, is not environmentally viable. In fact, hydrogen fuel can be produced by electrolysis with renewable energy sources such as solar and wind energy. The Hong Kong Government is also leading the application of renewable energy in public works, as stated in the "Climate Change Action Plan 2030+" (Environment Bureau, 2017). To enjoy the economies of scale, the government can even invite bus operators to introduce hydrogen buses, whose technology has been already been proven in many developed countries like the US and Japan. The production, operation and maintenance of the hydrogen fuel system can be shared among the rail and bus operators. The public transport operating costs can thus be lowered, thereby reducing even more carbon emissions. (Institution of Mechanical Engineers, 2019).

Considering the substantial costs of investment in the hydrogen train system, the government and the regulator can initiate a medium-term, say five-year, pilot operation in one of the new projects. Among these three greenfield projects, the Northern Link is considered primarily to have the most potential for the application of hydrogen train, given its mostly plain geographical nature, strict environmental conservation requirements and the mostly straightforward infrastructure construction. The hydrogen fuel cell system can be replaced by the OHL system after the pilot study, in case hydrogen is deemed an inviable choice of power sources. A comprehensive engineering survey and analysis is required to discuss this recommendation in detail.

\section{Conclusion}

At the beginning of the decade in 2020, the power sources being used in Hong Kong transport vehicles are still heavily reliant on petrol, diesel and electricity. These energy sources are indeed fundamentally extracted from fossil fuels. To curtail global warming, Hong Kong has to take the initiative in encouraging the use of alternative renewable energies. The hydrogen fuel cell could be a promising solution in the railway application, given its emission-free nature. While engineering, environmental and financial analyses are required to evaluate the feasibility of building a hydrogen train system, the government and rail operator can consider the socio-economic benefits brought by the hydrogen train: carbon emission reduction, development in the renewable energy industries, and enhancement of Hong Kong's reputation as an innovative and liveable city.

Still, the safety and reliability concerns and worries of communities and passengers must be investigated and addressed in detailed risk assessments. In addition, renewable energy sources such as wind and solar power should be utilised for producing hydrogen fuels to minimise carbon emissions. The government can also grasp this opportunity to introduce the hydrogen bus and enjoy the economies of scale by sharing the operating and maintenance costs of hydrogen fuel facilities. A medium-term pilot operation in the Northern Link, which is a greenfield project, is also recommended for the first introduction of the hydrogen train system. The operational performance can be evaluated after the pilot study, and converted back to the conventional OHL system if it is deemed inviable.

\section{Appendix 1 - Estimation of carbon emission reduction in the application of hydrogen trains}

Table 1. Estimation of carbon emission reduction in three Hong Kong greenfield projects.

\begin{tabular}{|l|c|c|c|}
\hline & Northern Link & $\begin{array}{c}\text { East Kowloon } \\
\text { Line }\end{array}$ & $\begin{array}{c}\text { South Island Line } \\
\text { (West) }\end{array}$ \\
\hline $\begin{array}{l}\text { Total route length } \\
(\mathrm{km}) \text { (Transport \& } \\
\text { Housing Bureau, } \\
2014)\end{array}$ & 10.7 & 7.8 & 7.4 \\
\hline $\begin{array}{l}\text { Estimated } \\
\text { daily patronage } \\
\text { (millions) }\end{array}$ & $0.758[\mathrm{a}]$ & $0.337[\mathrm{~b}]$ & $0.11[\mathrm{c}]$ \\
\hline $\begin{array}{l}\text { Annual passenger- } \\
\text { mileage (persons- } \\
\text { km) }\end{array}$ & $2.96 \times 10^{9}$ & $9.59 \times 10^{8}$ & $2.97 \times 10^{8}$ \\
\hline $\begin{array}{l}\text { Annual carbon } \\
\text { emission reduction } \\
\text { (tons) }\end{array}$ & 133764 & 43337 & 13421 \\
\hline
\end{tabular}

\section{Assumptions}

(a) Obtained by averaging the average weekday daily patronage on West Rail Line and East Rail Line in 2014 (HKSAR Government, n.d.).

(b) Obtained by referring to the average weekday daily patronage on Tseung Kwan O Line in 2014 (HKSAR Government, n.d.).

(c) Obtained by referring to the average weekday daily patronage on South Island Line (East) in 2017 (Mak, 2017). 


\section{Notes on contributor}

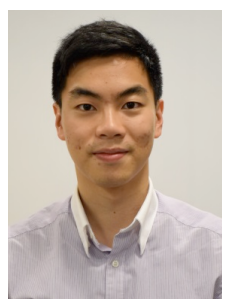

Mr Jacky Ping Pan Chan is a seasoned railway engineer in Hong Kong. He is interested in railway technology research and development. He recently obtained a master degree in transport policy and planning from The University of Hong Kong.

\section{References}

[1] Alstom (2020). Coradia iLint - the world's 1st hydrogen powered train. [Online].Available at: $<$ https://www.alstom.com/our-solutions/rolling-stock/ coradia-ilint-worlds-1st-hydrogen-powered-train>. [Accessed on 18 July 2020].

[2] BBC News (2019). Climate change: Should you fly, drive or take the train?. [Online].Available at: <https://www.bbc.com/news/scienceenvironment-49349566>. [Accessed on 18 July 2020].

[3] Environment Bureau, (2017). Climate Change Action Plan 2030+. [Online]. Available at: <https://www.enb. gov.hk/sites/default/files/pdf/ClimateActionPlanEng. pdf $>$. [Accessed on 18 July 2020].

[4] HKSAR Government (2020). Population. [Online]. Available at: <https://www.censtatd.gov.hk/hkstat/sub/ so20.jsp $>$. [Accessed on 18 July 2020].

[5] HKSAR Government (n.d.). Weekday Patronage of MTR Heavy Rail Network from September 1 to December 15, 2014. [Online]. Available at: <https://gia.info.gov.hk/general/201412/17/ P201412170530_0530_139306.pdf $>$. [Accessed on 18 July 2020].

[6] Institution of Mechanical Engineers (2019). The Future for Hydrogen Trains in the UK. [Online]. Available at: <https://www.imeche.org/policy-andpress/reports/detail/the-future-for-hydrogen-trains-inthe-uk>. [Accessed on 18 July 2020].

[7] Keyser W (2018). Pest Analysis - Means To Identify Political, Economic, Social \& Technological Factors. [Online]. Available at: $<$ https://venturefounders.com/ pest-analysis/>. [Accessed on 18 July 2020].

[8] Mak CW (2017). 南港島綫客少預期 35\%. [Online]. Available at: <https://hk.news.appledaily.com/local/ daily/article/20170114/19896532>. [Accessed on 18 July 2020].

[9] Matthew (2013). The World's First MassProduction of FCEV. [Online]. Available at: <http:// www.businesskorea.co.kr/news/articleView. html?idxno=552>. [Accessed on 18 July 2020].

[10] The Environmental Literacy Council (2015). Hydrogen Fuel Cells. [Online]. Available at: $<$ https:// enviroliteracy.org/energy/hydrogen/hydrogen-fuelcells/>. [Accessed on 18 July 2020].
[11] Transport \& Housing Bureau (2014). Railway Development Strategy 2014, Hong Kong: HKSAR Government.

[12] United Nations (2020). What is the Paris Agreement?. [Online]. Available at: $<$ https://unfccc.int/processand-meetings/the-paris-agreement/what-is-the-parisagreement>. [Accessed on 18 July 2020].

[13] Verdict Media Limited (2020). Coradia iLint Regional Train. [Online]. Available at: $<$ https://www.railwaytechnology.com/projects/coradia-ilint-regional-train/>. [Accessed on 18 July 2020]. 